\title{
Relationship Between Solid Waste Service Characteristics and Income Level in Metropolitan Bandung Raya
}

\author{
${ }^{1}$ SRI MARYATI, ${ }^{2}$ AN NISAA' SITI HUMAIRA, ${ }^{3}$ HUSNA TIARA PUTRI \\ 1,2,3 Kelompok Keahlian Sistem Infrastruktur Wilayah dan Kota, Sekolah Arsitektur, Perencanaan \\ dan Pengembangan Kebijakan ITB, Jl. Ganesha 10, Bandung 40132 \\ email: ${ }^{1}$ smaryati@pl.itb.ac.id, ${ }^{2}$ annisaa.sitihumaira@gmail.com, ${ }^{3}$ husnatiara@ymail.com
}

\begin{abstract}
Rapid urbanization process has stimulated the emergence of the metropolitan area, including Metropolitan Bandung Raya. Unfortunately, the development of the metropolitan region is not equipped by infrastructure. Generally, the level of service of infrastructure varies based on income level. The purpose of this research is to identify the relationship between solid waste service characteristics and household income level. Solid waste service characteristics are measured from waste handling and disposal, waste collection officers, the frequency of waste collection, and fees and payment. The results of the analysis show that there is a relationship between solid waste service and income level: the higher the income, the better the solid waste service. The followings are some significant findings found in this research: (a) solid waste service in housing developed by the developer is better compared to those in self-help housing, and (b) solid waste service in the urban area is better compared to those in suburban and rural area.
\end{abstract}

Keywords: income level, metropolitan bandung raya, service, solid waste infrastructure

\section{Introduction}

Rapid urbanization process has increased urban population significantly. This process generates the growth of metropolitan area, among others, Metropolitan Bandung Raya (MBR). This vast development is unaccommodated by the core area, particularly in the context of land availability. Due to this phenomenon, suburban area is arising and it becomes the most active area of urbanization process. Allen, etc. (2004) predicted that in 5 decades ahead, world population growth would occur in urban area with its emergence of spatial expansion in the suburbs and metropolitan area. The population growth in the core city will greatly decline, while the population growth in its surrounding areas will rise (Firman, 2009).

The development in metropolitan area generally is not followed by adequate infrastructure, especially for low income people. Infrastructure has multiple roles since it is not the main goal. Infrastructure is a means to achieve wider goals. Warsilan and
Noor (2015) stated that infrastructure has a role in absorbing employment, accelerating economic growth, and reducing poverty. Infrastructure provision is essential to becoming a priority for obtaining more development goals.

The condition of infrastructure provision for high-middle income is mostly much better compared to those of low-income people. According to Firman (2004) and Hudalah, dkk (2007), the emergence of metropolitan area brings up spatial segregation caused by housing development developed by developer. Firman (2004) pointed out that this phenomenon occurred in Jakarta Metropolitan Area where developers of high-middle income level delivered basic infrastructure exclusively for the residents. Gulyani, dkk (2010) expressed that many residents of self-housing who are classified as low-income people are unserved of basic services, such as clean water provision and solid waste service. These low-income people commonly provide self-help initiative of infrastructure services which tend to the

Received: May 24, 2016, Revision: November 15, 2016, Accepted: December 19, 2016

Print ISSN: 0215-8175; Online ISSN: 2303-2499. Copyright@2016. Published by Pusat Penerbitan Universitas (P2U) LPPM Unisba Accredited by DIKTI. SK Kemendikbud, No.040/P/2014, valid 18-02-2014 until 18-02-2019 
need-driven instead of policy-driven (Allen, dkk, 2006). Late intervention from the government in delivering infrastructure in the form of centralized system is more challenging to be held, considering low population density that makes the implication of high infrastructure provision cost (Maryati, dkk, 2010).

Solid waste is one of the infrastructures that require certain attention. Solid waste management is a crucial problem resulted from the urban growth (Faizah, 2008). Solid waste management faced with a number of challenges which cover amount and complexity of waste type (Rahab and Widiyanto, 2015). Waste production gradually rises as the increasing of population and their activities that slowly but surely will contribute to the complexity of the environmental urban problem.

This far, characteristic of solid waste service based on income level is still unknown yet in MBR. As discussed before, this spatial phenomenon in providing infrastructure is presumed to have some impact to the spatial segregation which is shown in the disintegration of infrastructure development among different income levels. Therefore, exploration and identification of infrastructure provision characteristic and its relationship with income level need to be done.

The result of this study can be used as a reference for a better future of policy formation in infrastructure provision in MBR.

\section{Quantitative Methods and Statistics Analysis}

The quantitative method with descriptive and association statistics analysis was used in this research. The general review of solid waste service characteristic in MBR was described using descriptive statistics analysis, while the conclusion of the relationship between solid waste service characteristic and income level was examined by association statistics analysis.

Association statistics analysis consists of a number of techniques that can be implemented, yet chi-square technique was chosen to be used in this research. It is able to test and perform the relationship between variables measured in nominal scale. This technique has a statistical hypothesis test based on null hypothesis conclusion which stated that if null hypothesis is accepted then there is no significant difference between the expected and observed results which in other words say that there is no correlation between observed variables. Null hypothesis is accepted if only chi-square observed value is bigger than the value in chi-square distribution table.

Income level variable and solid waste service variable are variables observed in this research. Income level variable is categorized into 7 classifications as follows: $(1)<\mathrm{Rp} 1$ million/month; (2) Rp 1 million/month - < Rp 2 million/month; (3) Rp 2 million/month - < Rp 3 million/month; (4) Rp 3 million/month - < Rp 4 million/month; (5) Rp 4 million/ month - < Rp 5 million/month; (6) Rp 5 million/month - < Rp 10 million/month; (7) $\geq$ Rp 10 million/month. On the other side, solid waste service variable consists of: (1) waste handling and disposal; (2) waste collection officer; (3) waste collection frequency; and (4) retribution and payment. Relationship between income level and solid waste service is tested in this research.

Variables of solid waste service were chosen based on solid waste management stages which consist of waste storage, collection, transfer, transport, and disposal. Waste storage, collection, and transport were chosen variables considering that they are directly related to the community as the source of waste generator producer. Meanwhile, transfer and disposal variables are not directly related to the community. The choice of variable that is directly related to the community will simplify the identification of the relationship between those variables and income level.

The analysis of this study is based on primary and secondary data. Primary data obtained from observation and structured questionnaire distribution to a number of households and related stakeholders, whilst secondary data was gathered from literature. 246 out of 562,846 households from selfhelp housing and also housing built by developer in MBR were observed as research samples. In accordance with Fraenkel, etc (2012), research samples calculation can be determined without considering calculation based on probability and/or level of confidence. For some research which is more descriptive, at least it needs 100 samples. Furthermore, for study that focuses on correlation, it needs at least 50 samples to determine the relationship between variables, and not less than 30 samples per group are required for conducting comparative study.

Samples were spread based on the 
distribution of formal housing built by developer in MBR area. Formal housing was chosen in order to cover all income level. After determining formal housing as housing sample observed, self-help housing that was closely located with formal housing was chosen as sample as well.

\section{Overview of Study Area and Solid Waste Service in Metropolitan Band- ung Raya}

MBR area encompasses 5 administrative regions which are Bandung City (30 districts), Cimahi City (3 districts), Bandung Regency (31 districts), West Bandung Regency (16 districts), and Sumedang Regency (5 districts). Bandung City, Cimahi City, a small part of Bandung Regency is classified into the core area of MBR, whereas the rest of the area is categorized as peri-urban area. In 2013, total population of MBR was $8,395,560$ people which were $18.5 \%$ of West Java population with total area of 350,923 ha and 23.92 people/ha of population density. Bandung Regency is the most populated and largest area among regions in MBR. Population density in MBR is varied within the range of 11.9 people/ha to 146.14 people/ha. The densest area is found in the core area of MBR which are in Cimahi City (138.59 people/ha) and Bandung City (146.14 people/ha). The details of those mentioned components of the study area can be seen in Table 1 .

Solid waste service characteristic is varied among administrative regions (see Table 2). Bandung Regency produces the largest amount of waste which is influenced by the most populated area among regions in MBR. If it is seen from its successfully transported waste and level of service, the best performance is shown by Bandung City. This condition cannot be separated from high

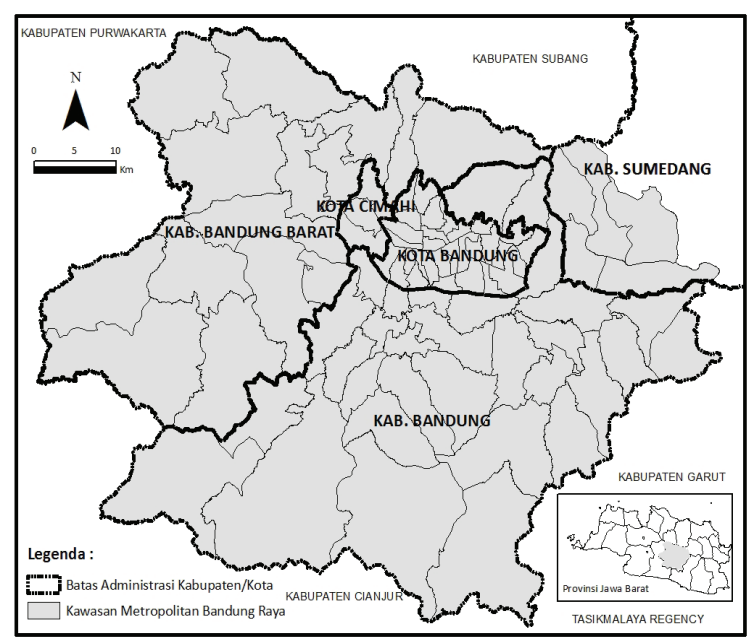

Figure 1. The Area of Metropolitan Bandung Raya

population density in this region, so that, waste transport and service is more effective to be conducted. Waste transport level and level of service in MBRT has not achieved $100 \%$ performance yet. Waste transport level and level of service in the core area, are generally better compared to those in suburban area that is affected by service coverage and population distribution. Core area encompasses smaller area with more centralized population distribution compared to peri-urban area. It surely makes solid waste service delivery to the community easier.

If the indicators of waste transport level and level of service are compared, then it can be seen that level of service indicator is higher than waste transport indicator. The level of service is the indicator that shows the percentage of total population served compared to total population, while waste transport indicator describes the total amount

Table 1

Population, Area, and Population Density in MBR

\begin{tabular}{clccc}
\hline No & Regency/City & $\begin{array}{c}\text { Population } \\
\text { (people) }\end{array}$ & Area (ha) & $\begin{array}{c}\text { Population Density } \\
\text { (people/ha) }\end{array}$ \\
\hline 1 & Bandung Regency & $3,405,475$ & 175,665 & 19.39 \\
2 & West Bandung Regency & $1,588,781$ & 133,560 & 11.9 \\
3 & Sumedang Regency* & 371,810 & 20,755 & 17.91 \\
4 & Cimahi City & 570,991 & 4,120 & 138.59 \\
5 & Bandung City & $2,458,503$ & 16,823 & 146.14 \\
& Total & $8,395,560$ & 350,923 & 23.92 \\
& West Java & $45,340,799$ & $3,717,397$ & 12.19 \\
\hline
\end{tabular}

Source: Statistics of West Java, 2013; Statistics of West Java, 2014; Statistics of Sumedang Regency, 2014 
of waste transported per day compared to total waste generation per day. Although these two indicators do not directly show the relationship between them, yet the value of these indicators indicates that the community served by solid waste service is quite many with some technical lack of waste transport and handling. This fact indicates two things: (1) solid waste infrastructure in MBR still needs some improvement; and (2) waste handling in MBR needs to be integrated with 3R concept (Reduce, Reuse, Recycle), specifically in the source. Implementation of $3 R$ concept enables waste reduction that should be transported from the source to temporary waste storage (TPS) and final disposal site (TPA).

$3 R$ concept has not implemented widely yet. On the other side, fairly good implementation is done in Cimahi City with $51.71 \%$ of performance value that indicates that waste volume can be reduced by $51.71 \%$. This achievement is affected by landslide tragedy in TPA Leuwigajah in 2005 , hence the local government has been implementing this concept in order to reduce waste volume transported to TPA. Some 3R concept applications in Cimahi City are composting, metal and glass recycling, and reselling plastic and paper waste. In other administrative regions, this implementation has not been well conducted, for instance, only $39 \%$ of the waste volume that can be reduced in Bandung City with 3R concept. Nevertheless, several waste bank groups have been developed to reduce the waste volume focused on non-organic waste management.

Table 2

Solid Waste Service in Metropolitan Bandung Raya

\begin{tabular}{|c|c|c|c|c|c|c|}
\hline & Criteria & $\begin{array}{l}\text { Bandung } \\
\text { Regency }\end{array}$ & $\begin{array}{c}\text { Sumed- } \\
\text { ang Re- } \\
\text { gency }\end{array}$ & $\begin{array}{c}\text { West } \\
\text { Bandung } \\
\text { Regency } \\
\end{array}$ & $\begin{array}{l}\text { Bandung } \\
\text { City }\end{array}$ & Cimahi City \\
\hline \multicolumn{7}{|c|}{ Performance of Solid Waste Service } \\
\hline \multirow{3}{*}{$\begin{array}{l}\text { Waste } \\
\text { Collection }\end{array}$} & $\begin{array}{l}\text { Municipal Waste } \\
\text { Generation }\end{array}$ & $3,969,275$ & 637,574 & $1,246,330$ & 5,647830 & $1,464,625$ \\
\hline & Waste Transported & $26 \%$ & $26 \%$ & $13 \%$ & $36 \%$ & $10 \%$ \\
\hline & Level of Service & $49 \%$ & $61 \%$ & $47 \%$ & $97 \%$ & $73 \%$ \\
\hline \multicolumn{7}{|c|}{ Technical Operation of Solid Waste Management } \\
\hline \multirow{4}{*}{$\begin{array}{l}\text { Waste } \\
\text { Transfer and } \\
\text { Transport }\end{array}$} & $\begin{array}{l}\text { Level of Service of } \\
\text { Temporary Waste } \\
\text { Storage (TPS) }\end{array}$ & $19.27 \%$ & $44.74 \%$ & $18.55 \%$ & $26.30 \%$ & $33.80 \%$ \\
\hline & $\begin{array}{l}\text { Waste Volume } \\
\text { Reduced Using 3R }\end{array}$ & $0 \%$ & $0 \%$ & $0 \%$ & $0.39 \%$ & $51.71 \%$ \\
\hline & $\begin{array}{l}\text { Total Final Disposal } \\
\text { Site (TPA) }\end{array}$ & 1 & 1 & 1 & 1 & 1 \\
\hline & $\begin{array}{l}\text { Final Disposal Site } \\
\text { (TPA) Location }\end{array}$ & Babakan & $\begin{array}{l}\text { Cibe- } \\
\text { reum } \\
\text { Wetan }\end{array}$ & Sarimukti & Sarimukti & Sarimukti \\
\hline \multirow[t]{3}{*}{$\begin{array}{l}\text { Waste } \\
\text { Disposal }\end{array}$} & $\begin{array}{l}\text { Total Final Disposal } \\
\text { Site (TPA) Area } \\
\text { (ha) }\end{array}$ & 11.20 & 12.00 & 21.00 & 21.00 & 21.00 \\
\hline & $\begin{array}{l}\text { Final Disposal Site } \\
\text { (TPA) Used (ha) }\end{array}$ & 4.5 & 6.7 & 18.0 & 18.0 & 18.0 \\
\hline & $\begin{array}{l}\text { Final Disposal Site } \\
\text { (TPA) Unused (ha) }\end{array}$ & 6.70 & 5.30 & 3.00 & 3.00 & 3.00 \\
\hline Authority & & $\begin{array}{l}\text { Housing, } \\
\text { Spatial } \\
\text { Plan- } \\
\text { ning, and } \\
\text { Sanitation } \\
\text { Depart- } \\
\text { ment }\end{array}$ & $\begin{array}{l}\text { Environ- } \\
\text { mental } \\
\text { Agency }\end{array}$ & $\begin{array}{l}\text { Sanitation } \\
\text { Technical } \\
\text { Implemen- } \\
\text { tation Unit }\end{array}$ & $\begin{array}{l}\text { Sanitation } \\
\text { Local } \\
\text { Enterprise }\end{array}$ & $\begin{array}{l}\text { Sanitation } \\
\text { and } \\
\text { Hygiene } \\
\text { Department }\end{array}$ \\
\hline
\end{tabular}

Source: Government of West Java Province, 2014 
This waste bank certainly helps in reducing the waste volume transported to TPS as well as TPA. On the contrary, Bandung Regency, Sumedang regency, and West Bandung Regency are not indicated yet as the regions that attempt to reduce the waste volume implementing 3R concept.

Regarding of TPS service and TPST (temporarily integrated waste storage), the best performance is shown by Sumedang Regency with $44,74 \%$ of TPS/TPST performance. TPS is a place where waste is stored before it is transported to another place for being recycled and/or processed, while TPST is a place where the waste is collected, sorted, reused, recycled, and processed. According to Government Regulation of Indonesia Number 81/2012 concerning domestic waste, TPS and TPST must be provided by manager/owner of residential/ settlement area, commercial area, industrial area, particularly are public and social facilities, and other facilities. If the owner/ manager of the area and/or facility cannot provide it, then local government has an obligation to provide it.

Final disposal site (TPA) is a place where the waste is finally processed and brought back to nature. The final process is conducted in TPA. West Bandung Regency, Bandung City, and Cimahi City utilize one TPA for those three regions, which is TPA Sarimukti, while Bandung Regency and Sumedang Regency respectively use their own TPA, which are TPA Babakan and TPA Cibeureum Wetan. The land remained of TPA that is still can be utilized is very limited. This matter indicates that: (1) a new TPA is needed, and (2) strong effort in reducing waste volume transported to TPA is certainly required. The effort in looking for a new location for TPA and/or expanding TPA are difficult to be done, considering land availability and rejection from the community if new TPA is located near to their settlement. It is also getting harder especially in the urban area like Bandung City and Cimahi City. Based on that fact, waste reduction attempt must be initiated.

Sanitation authority in MBR is quite different. Related department of each local government both in Bandung Regency and Cimahi City is being an authority, while it is managed by an agency in Sumedang Regency and technical implementation unit in West Bandung Regency. Local enterprise is also involved in managing the waste in Bandung City.

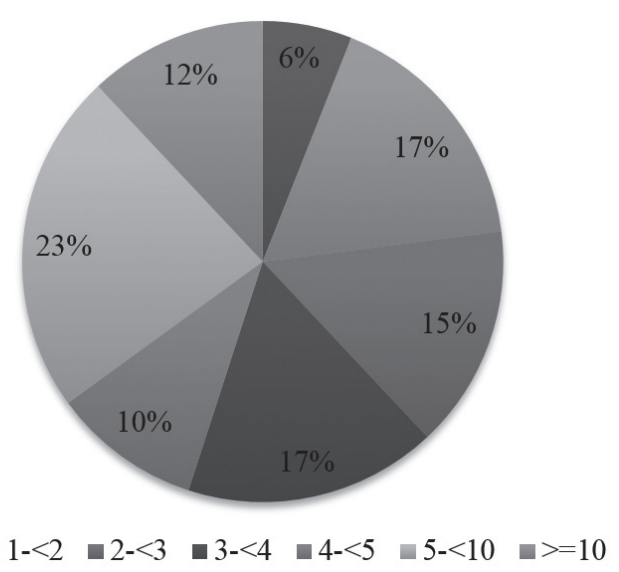

Figure 2. Distribution of Respondents Income Level (Million Rupiah/month)

\section{Characteristic of Respondents Income Level}

The highest percentage of respondent's income level is in the range of Rp 5 million/ month to Rp 10 million/month which is $23 \%$. If the range is in between Rp 1 million/month to less than Rp 5 million/month combined into one classification, then it can be the biggest percentage of all (59\%). Nonetheless, in this research those range is not combined due to various service covered in those range. Meanwhile, a variation of this service in the range of Rp 5 million/month to Rp 10 million/ month is not significantly seen. Respondents income level distribution can be seen in Figure 2.

This varied respondent's income level is spread either in formal housing built by developer or self-help housing. There are 119 respondents who reside in formal housing located in the core area (70 respondents), peri-urban area (38 respondents), and rural area (11 respondents), while 127 respondents dwell in self-help housing with respondent's distribution respectively as followed: 70,38 , and 19 for the core, peri-urban, and rural area.

The number of house unit in informal housing is varied which can be only 10 units (Private Village, Bandung Regency) or hundreds unit, such as in Perumahan Setradago (Bandung City), Kota Baru Parahyangan (West Bandung Regency), Dago Pakar (Bandung City), Manglayang Regensi (Bandung Regency), and Metro Soekarno Hatta Estate (Bandung City). From those number, some housings are still managed by the developer, whilst the rest of them is managed by their own residents. 


\section{Relationship Between Solid Waste Service Characteristics and Income Level}

In general, solid waste management directly related to the community can be categorized based on 3 aspects: handling and disposal, collection and, transfer.

\section{Waste Handling and Disposal}

In the term of waste disposal, most respondents $(82 \%)$ have disposed the waste into their own dustbin while only $7 \%$ respondents disposed the waste directly to TPS and the rest of $11 \%$ processed the waste, so that they do not dispose it. Generally, handling and disposal performance have already achieved good performance which is proven by $89 \%$ respondents who dispose the waste in its proper place. Most respondents who disposed the waste directly to TPS are respondents with income level of $<$ Rp 4 million and respondents who process the waste are likewise. Table 3. reports concerning waste handling characteristic based on level income.

Waste which is not disposed to TPS is processed in the form of backfilled, burned, sold to the secondhand merchant, or dumped into the river. Mostly, waste burning is a common option for the community who do not dispose the waste to TPS.

As discussed before, it is known that low-middle income level group do not disposed the waste to TPS, yet they processed the waste on their own. It is observed that their own way in waste handling is influenced by the lack of solid waste service delivered to this group, such as no individual/ communal trashbin/ container.

Waste container provision at the source is an obligation of individual house or manager of settlement/housing area, yet some reasons as the cause of unavailability of individual trash bin/container are as follows: (1) low economic affordability; and (2) limitation in physical and environmental settlement caused by high population density or inadequate area of each house unit or rugged topography in settlement area. In this individual case, at the minimum, communal trash container should be provided by the authority of the area as well as government.

Waste processing is mostly done by $18 \%$ respondents in self-help housing while only $2.5 \%$ respondents informal housing do the same way. Viewed from its location, it is distributed in a rural area $(16.7 \%)$, peri urban area $(10.5 \%)$ and followed by the core area for only $9.2 \%$ respondents. From that point of view, we can say that unhandled waste is still found due to a poor temporary waste storage system that happens mostly for low-income people group who reside in self-help housing in the rural area.

Important thing related to waste handling and disposal lies in sorting behavior. Waste sorting will certainly determine further waste handling, such as $3 \mathrm{R}$ concept. This waste sorting has not been considerably conducted yet in MBR. Only 46 out of 246 respondents $(18.7 \%)$, with most of them (69.9\%) have less than Rp 5 million/month for their income, have implemented this waste sorting. Table 4, represents waste sorting characteristics based on income level.

Table 3

Characteristic of Waste Handling based on Income Level

\begin{tabular}{ccccc}
\hline $\begin{array}{c}\text { Income (million } \\
\text { rupiah/month) }\end{array}$ & $\begin{array}{c}\text { Waste Handling and Disposal } \\
\text { Disposed to } \\
\text { Individual Dust- } \\
\text { Bin }\end{array}$ & $\begin{array}{c}\text { Disposed to } \\
\text { Temporary } \\
\text { Waste Storage } \\
\text { (TPS) }\end{array}$ & $\begin{array}{c}\text { Undisposed/ } \\
\text { Processed }\end{array}$ & Total \\
\hline$<1$ & 10 & 1 & 4 & 15 \\
$1-<2$ & 23 & 8 & 10 & 41 \\
$2-<3$ & 24 & 5 & 7 & 36 \\
$3-<4$ & 37 & 2 & 3 & 42 \\
$4-<5$ & 23 & 1 & 0 & 24 \\
$5-<10$ & 56 & 1 & 1 & 58 \\
$>=10$ & 29 & 0 & 1 & 30 \\
Total & $\mathbf{2 0 2}$ & $\mathbf{1 8}$ & $\mathbf{2 6}$ & $\mathbf{2 4 6}$ \\
\hline
\end{tabular}


MIMBAR, Vol. 32, No. $2^{\text {nd }}$ (December, 2016), pp. 233-242

Table 4

Characteristic of Waste Sorting based on Income Level

\begin{tabular}{cccc}
\hline $\begin{array}{c}\text { Income (million } \\
\text { rupiah/month) }\end{array}$ & \multicolumn{2}{c}{ Waste Sorting } & Total \\
\hline$<1$ & 4 & Unsorted & 11 \\
$1-<2$ & 7 & 34 & 15 \\
$2-<3$ & 8 & 28 & 41 \\
$3-<4$ & 7 & 35 & 36 \\
$4-<5$ & 6 & 18 & 42 \\
$5-<10$ & 10 & 48 & 24 \\
$>=10$ & 4 & 26 & 58 \\
Total & 46 & 200 & 30 \\
\hline
\end{tabular}

Table 5

Characteristic of Waste Collection Officer based on Income Level

\begin{tabular}{cccccc}
\hline $\begin{array}{c}\text { Income } \\
\text { (million } \\
\text { rupiah/month) }\end{array}$ & $\begin{array}{c}\text { Neighborhood/ } \\
\text { Community } \\
\text { Unit }\end{array}$ & $\begin{array}{c}\text { Waste Collection Officer } \\
\text { Housing } \\
\text { Manager }\end{array}$ & $\begin{array}{c}\text { Local } \\
\text { Government }\end{array}$ & Others & Total \\
\hline$<1$ & 9 & 0 & 2 & 0 & 11 \\
$1-<2$ & 27 & 1 & 3 & 0 & 31 \\
$2-<3$ & 24 & 1 & 4 & 0 & 29 \\
$3-<4$ & 28 & 5 & 4 & 2 & 39 \\
$4-<5$ & 19 & 0 & 5 & 0 & 24 \\
$5-<10$ & 36 & 14 & 7 & 0 & 57 \\
$>=10$ & 13 & 10 & 5 & 1 & 29 \\
Total & 156 & 31 & 30 & 3 & 220 \\
\hline
\end{tabular}

\section{Transfer and Transport Officers}

Waste collection officer in this context is the officer who collects the waste from its source to TPS or directly to TPA. As informed by respondent, the officer is either from neighborhood/community unit, housing manager, or local government. Respondents who do not dispose the waste to TPS/ individual processing as mentioned before are not included in this analysis part.

Most respondents reported that the waste transfer officer was from their neighborhood/community unit. This fits with the fact and regulation in Indonesia which stated that waste transfer at its source or household to TPS is held by the community, while local government handles waste transport from TPS to TPA. In some specific locations, such as in the rugged topography location and/or located near to TPA, local government also handles waste transfer from the household. In line with the Regulation of
Ministry of Home Affairs Number 33/2010 regarding Solid Waste Management Guidance and Government Regulation Number 81/2012 regarding Domestic Solid Waste Management, it is stated that waste transfer and transport is an obligation of solid waste management officer formed by neighborhood/community unit, local government, or manager/owner of an area. Waste management authority formed by neighborhood/community unit is responsible for transferring waste from household to TPS/TPSTL, while local government transports it from TPS/TPST to TPA, and manager/owner of an area is also responsible for transporting the waste from its source to TPS/TPST and/or TPA.

Waste transfer officers that come from formal housing/area are mostly found in the housing with high-middle income respondents. This indicates that independently well infrastructure provision managed in particular housing which is commonly inhabited by highmiddle income people group. 
Interesting finding concerning waste transfer officer and implementation of Government Regulation Number 81/2012 is not every developer or manager of an area provide this service. Only $29(24.4 \%)$ out of 119 respondents who reside in formal housing built by the developer are served by developer for this service. $55.6 \%$ respondents are served by neighborhood/community unit, whilst $16 \%$ remained served by local government. This condition draws that not all developers provide waste transfer and transport service due to the area scale developed by developer. Commonly, small scale housing does not serve waste transfer and transport as it is not efficient. Housings built by the developer are spread in the core area (24.3\%), periurban area $(26.3 \%)$, and rural area $(18.2 \%)$. Table 5 shows characteristic of waste transfer and transport based in income level.

\section{Waste Collection Frequency}

In accordance with the Regulation of the Ministry of Public Work Number 03/ $\mathrm{PRT} / \mathrm{M} / 2013$, it is stated that waste collection is supposed to be done every 1-3 days with its frequency of 1-4 times per day. Based on respondent's information, waste collection is done in every $1-3$ days (51\%). On the other hand, $28.5 \%$ respondents (mostly low-middle income people) informed that waste collection frequency was uncertain. Table 6 . shows the characteristic of waste collection frequency based on income level.

If it is seen from housing distribution, most respondents acquiring waste collection service with normal frequency (in line with standard) reside in formal housing built by the developer (76\%). Similarly, respondents who acquire uncertain waste collection

Table 6

Characteristic of Waste Collection Frequency based on Income Level

\begin{tabular}{cccccccc}
\hline $\begin{array}{c}\text { Income } \\
\text { (million } \\
\text { rupiah/ } \\
\text { month) }\end{array}$ & $\begin{array}{c}\text { Every- } \\
\text { day }\end{array}$ & $\begin{array}{c}\text { Every 2 } \\
\text { Days }\end{array}$ & $\begin{array}{c}\text { Waste Collection Frequency } \\
\text { Every 3 } \\
\text { Days }\end{array}$ & $\begin{array}{c}\text { Once a } \\
\text { Week }\end{array}$ & Uncertain & Uncollected & Total \\
\hline$<1$ & 1 & 0 & 3 & 2 & 3 & 6 & 15 \\
$1-<2$ & 5 & 5 & 6 & 2 & 5 & 18 & 41 \\
$2-<3$ & 7 & 3 & 6 & 5 & 0 & 15 & 36 \\
$3-<4$ & 8 & 8 & 8 & 8 & 4 & 6 & 42 \\
$4-<5$ & 6 & 4 & 9 & 3 & 0 & 2 & 24 \\
$5-<10$ & 16 & 11 & 17 & 8 & 3 & 3 & 58 \\
$>=10$ & 8 & 7 & 8 & 2 & 2 & 3 & 30 \\
Total & $\mathbf{5 1}$ & $\mathbf{3 8}$ & $\mathbf{5 7}$ & $\mathbf{3 0}$ & $\mathbf{1 7}$ & $\mathbf{5 3}$ & $\mathbf{2 4 6}$ \\
\hline
\end{tabular}

Table 7

Characteristic of Waste Retribution Payment based on Income Level

\begin{tabular}{ccccccc}
\hline $\begin{array}{c}\text { Income } \\
\text { (million } \\
\text { rupiah/month) }\end{array}$ & $\begin{array}{c}\text { Through } \\
\text { Neighborhood/ } \\
\text { Community Unit }\end{array}$ & $\begin{array}{c}\text { Waste Retribution Payment } \\
\text { Through } \\
\text { Housing } \\
\text { Manager }\end{array}$ & $\begin{array}{c}\text { Directly to } \\
\text { the Sanitation } \\
\text { Officer }\end{array}$ & Not Paying & Total \\
\hline$<1$ & 7 & 0 & 2 & 6 & 15 \\
$1-<2$ & 19 & 1 & 5 & 16 & 41 \\
$2-<3$ & 20 & 1 & 4 & 11 & 36 \\
$3-<4$ & 28 & 1 & 10 & 3 & 42 \\
$4-<5$ & 15 & 4 & 4 & 1 & 24 \\
$5-<10$ & 38 & 14 & 4 & 2 & 58 \\
$>=10$ & 15 & 9 & 5 & 1 & 30 \\
Total & 142 & 30 & 34 & 40 & 246 \\
\hline
\end{tabular}


MIMBAR, Vol. 32, No. $2^{\text {nd }}$ (December, 2016), pp. 233-242

Table 8

Relationship between Solid Waste Service Criteria and Income Level

\begin{tabular}{lccc}
\hline \multicolumn{1}{c}{ Criteria } & $\begin{array}{c}\text { Observed } \\
\text { Value } \\
\text { (Chi-Square) }\end{array}$ & $\begin{array}{c}\text { Expected Value } \\
\text { (Chi-Square } \\
\text { Distribution Table) }\end{array}$ & Conclusion \\
\hline Waste Handling and Income Level & 46,23 & 21,03 & Related \\
Waste Transfer Officer and Income Level & 76,89 & 36,42 & Related \\
Waste Collection Frequency and Income & 61,65 & 43,77 & Related \\
Level & 70,47 & 28,87 & Related \\
Retribution Payment and Income Level & & & \\
\hline
\end{tabular}

service does not mean getting better service in waste collection compared to those in formal housing, which are $45.7 \%$ in self-help housing and $10.6 \%$ informal housing. It can be concluded that service for waste collection informal housing has better performance than in self-help housing.

Good service in the waste collection is distributed respectively from the highest in the core $(63.6 \%)$, periurban $(57.9 \%)$, and rural area $(43.3 \%)$.

\section{Retribution and Payment}

Retribution is a fee paid of solid waste service acquired that costs from Rp 5,000/ month to Rp 150,000/month. Most retribution is paid through neighborhood/community unit that has delivered the service to the community. Nonetheless, there are also retribution paid via housing manager or directly to sanitation officer. $16 \%$ respondents informed that they did not pay retribution and these respondents were mostly categorized as low-middle income group. Table 7. Informs characteristic of retribution and its payment based on income level.

Relationship test between waste handling and disposal, waste collection frequency, and retribution and payment with income level variable using chi-square shows that there are relationships between those mentioned criteria with income level, as seen in Table 8.

\section{Conclusions}

Based on the analysis regarding solid waste service condition and income level, it can be concluded that this kind of services are acquire better for high-middle income group, compared to those low-middle income group. Unavailability of solid waste infrastructure or in other words lack of access to solid waste infrastructure causes respondents dispose and handle the waste inappropriately, such as burning and dumping the waste into the river.

Interesting finding lies in waste sorting behavior that low-middle income respondents implement more waste sorting compared to high-middle income group. Solid waste service is still dominated independently by the community that is managed by neighborhood/ community unit, event though there also a service handled by the housing authority and local government.

Another interesting finding is concerning on various services among housings (formal and self-help housing) and its location. Categorized by type of housing, solid waste service in formal housing performs better rather than in self-help housing. On the other hand, seen from its location, this service shows the best performance in the core area, above of suburban and rural area.

Referring to the result of analysis, it is recommended that local government in MBR area needs to intervene in handling and managing the solid waste service, especially for low-middle income group. Solid waste service characteristic examined in this study is the service managed by community or developer. The analysis shows that lowmiddle income group is unable to manage their waste service independently. Therefore, interventions that can be given are by providing communal waste container/bin (temporary storage) and providing service in waste transfer and transport from communal waste container/bin (temporary storage) to TPS as well as TPA. Solid waste management in the form of implementing $3 R$ concept is also potential to be conducted. The government needs to initiate the establishment of waste management groups that focus on $3 \mathrm{R}$ concept implementation. 


\section{References}

Allen, A., Dávila, J., and Hofmann, P. (2004). 'Governance and access to water and sanitation in the metropolitan fringe: an overview of five case studies', Proceeding: the 5th N-Aerus Annual Conference: Urban Governance, Diversity and Social Action in Cities of the South, 15-16 September, Barcelona Spanyol.

Allen, A., Dávila, J., and Hofmann, P. (2006). 'Governance of Water and Sanitation Services for the Peri-urban Poor: A Framework for Understanding and Action in Metropollitan Regions', the Development Planning Unit University College London.

Faizah.(2008). 'Pengelolaan Sampah Rumah Tangga Berbasis Masyarakat', Tesis Magister, Universitas Diponegoro.

Firman, T. (2004). 'New town development in Jakarta Metropolitan Region: a perspective of spatial segregation', Habitat International, Vol.28, No.3, pp.349-368.

Firman, T. (2009). 'The continuity and change in mega-urbanization in Indonesia: a survey of Jakarta-Bandung Region (JBR) development', Habitat International, Vol.33, No.4, pp.327-339.

Fraenkel, J. R., Wallen, N. E., and Hyun, H. H. (2012). 'How to Design and Evaluate Research in Education', Eight Edition, McGraw-Hill.

Gulyani, S., Debrata, T., and Darby, J. (2010). 'Poverty, Living Conditions, and Infrastructure Access: a comparision of slums in Dakar, Johannesburg and Nairobi', Policy Research Working Paper 5388, The World Bank, Africa Region, Sustainable Development Division.

Hudalah, D., Winarso, $\mathrm{H}$ and Woltjer, $\mathrm{J}$.
(2007). 'Peri-urbanisation in East Asia: a new challenge for planning?', International Development Planning Review, Vol.29, No.4, pp.501-517.

Maryati, S. and Pradono (2010). 'Spatial Strategy in Improving Access to Water Supply in Urban Areas', Proceeding: AIT$\mathrm{KU}$ Joint Symposium on Human Security Engineering, 25-26 November, Bangkok Thailand, pp.11-19.

Peraturan Menteri Dalam Negeri Nomor 33 Tahun 2010 tentang Pedoman Pengelolaan Sampah.

Peraturan Menteri Pekerjaan Umum Republik Indonesia Nomor 03/PRT/M/2013 tentang Penyelenggaraan Prasarana dan Sarana Persampahan dalam Penanganan Sampah Rumah Tangga dan Sampah Sejenis Sampah Rumah Tangga.

Peraturan Pemerintah Nomor 81 Tahun 2012 tentang Pengelolaan Sampah Rumah Tangga dan Sampah Sejenis Sampah Rumah Tangga.

Rahab dan Widiyanto, A.F. (2015). 'Pengujian Model Pengaktivasian Norma Personal dalam Perspektif Pemasaran Sosial', MIMBAR - Jurnal Sosial dan Pembangunan, Vol.31, No.1, pp.177-190.

Statistics of West Java.(2013). 'West Java dalam Angka 2013'.

Statistics of West Java. (2014). 'West Java dalam Angka 2014'.

Statistics of Sumedang Regency. (2014). 'Sumedang Regency dalam Angka 2014'.

Warsilan dan Noor, A. (2015). 'Peranan Infrastruktur terhadap Pertumbuhan Ekonomi dan Implikasi pada Kebijakan Pembangunan di Kota Samarinda', MIMBAR, Jurnal Sosial dan Pembangunan, Vol.31, No.2, pp.359-366. 